\title{
Employer Branding Practices in Saudi Arabian Banking Sector
}

\author{
Dr. Nisar Ahamad Nalband \\ Associate Professor \\ College of Business Administration, King Saud University \\ E-mail: nnalband@ksu.edu.sa \\ Dr. Mohammed A. Al Awadh \\ Assistant Professor \\ College of Business Administration, King Saud University \\ E-mail: malawadh@yahoo.com
}

Received: May 14, 2017

Accepted: June 21, 2017

Published: July 1, 2017

doi:10.5296/jmr.v9i3.11223

URL: https://doi.org/10.5296/jmr.v9i3.11223

\begin{abstract}
In these days of competition, to be unique in the market the organizations are using many strategies. To design and execute any strategy the organizations needs talented employees.

To facilitate the pooling of employees into an organization "employer branding practices" plays a critical role. In the process of attracting the right talent at right time for right job has become immensely important. The human resources management departments have no doubt occupying the fore front in the business organizations of today; yet it has to leave its impact through communicating the employer branding practices properly in an effective way.

The present research paper deals with Saudi Arabian Banking Sector where in which the authors have made an attempt to find the practices of employer branding available or not from the human resource management perspective.

The research is timely for the reason that Saudi Arabia is implementing "Nitaqat" (a step by step process to encourage local's employment (the Saudi employment market comprises around $40 \%$ of expatriate employees). The companies are on toes to recruit Saudi nationals; the availability of skilled and talented Saudis is less. Therefore there is a need for employer branding practices.
\end{abstract}




\section{Macrothink}

Journal of Management Research

ISSN 1941-899X

2017, Vol. 9, No. 3

The data collected from thirteen banks operating in Saudi Arabia and appropriate tools of statistics used to analyze the data and arrive to a conclusion.

From the literature review it is found that academically unanimously it is agreed that employer branding practices will help in attracting and retaining the talent, but the actual practices of employer branding are either not recorded or properly planned. From the research it is found that definitely there is a need for employer branding practices in Saudi Arabian banking sector too.

Keywords: Employer band, Practices, Banking sector, Saudi Arabia, Branding 


\section{Introduction}

As rightly mentioned by an author "if there is any world war going to happen it's not going to be for water but it's going to be for talent". The world is going global, digital, herbal and spiritual. The world economy been driven mostly by brainwork than physical work; knowledge workers knows the means of their production that is their knowledge. The world across the scenario is the same; that the successful organizations have talented employees. The organizations from each other, are trying to pull the star performers, these circumstances made it eventual for the organizations to create a reputation for them to attract and retain the best talent available in the labor market and from the competitors firms. So it is important for the organizations to develop adequate and appropriate plans and put efforts to attract the best pool of available candidates and to nurture and retain the current employees (Rucci, Kirn, \& Quinn, 1998).

In marketing terms, the word "brand" is, like any reputation, linked to what an individual believes about a specific product or service of a company. A brand is essentially a promise of commitment and performance by an organization. Successful brands are those that consistently deliver on their promises (Campbell, 2002) and are supported and reinforced by the senior management team of the organization. Brand helps to communicate what it is like to work for that particular organization and what the organization stands for; it is an unique value proposition to potential and existing employees (Caplan, 2004).

Many authors are of the opinion that brands and human capital constitute some of the firm's most important assets (Aaker, 1991; Backhaus \& Tikoo, 2004), the development of these intangible assets is an important task for marketers and human-resource managers (Sutherland, Torricelli, \& Karg, 2002). In the context of employer marketing, the employer brand is to be understood as the set of distinctive images of a prospective employer, which are manifest in the minds of the target groups - potential employees (Meffert, Burmann, \& Koers, 2002; Petkovic, 2004).

The term 'Employer Brand' first coined in early 1990; the term was meant for "understanding organization's reputation as an employer", basically, it meant for distinguishing the employers. Ambler and Barrow (1996) defined the term as "The package of functional, economic, and psychological benefits provided by employment, and identified with the employing company". Another author, Minchington (2010); defined it as "the image of organization as a great place to work in the mind of current employees and key stakeholders in the external market (active and passive candidates, clients, customers and other key stakeholders).The art and science of employer is therefore is concerned with the attraction, engagement and retention initiatives targeted at enhancing company's employer brand"."Employer branding is the development and communication of an organization's culture as an employer in the market place." (Mandhanya \& Maitri, 2010). In rapidly changing dynamic environment, the endurance and attainment of organizations depend upon the quality of workforce, which can adapt to the changes. The great challenge for the organizations of today is to attract and retain the best talent.

These days are market-oriented days; it has become very difficult to attract and retain the 
employees so the organizations need to have long-term strategies in attracting and retaining the talent (Taylor, 2010). There are plenty of opportunities available to the people across the globe; the people are also becoming global because of the high-speed transportation and telecommunication facilities.

The author, Fill (2006), what he spoke about DRIP (differentiate, reinforce, inform and persuade) in terms of marketing communication need to be adapted to employer branding also because the employer in the process of attracting and retaining the employees need to differentiate with other employers, reinforce the employer image by communicating effectively to prospective and present employees to attract and retain respectively. Taylor (2010) pointed out that having an employer brand definitely helps in becoming "employer of choice", further the organization with good branding definitely rope in the best talent with least hiring costs last but not the least benefit is organizations can witness best employee performance.

Besides the economic crunch in countries, fluid movement of the labor markets, above and over availability of skilled human resources in some of the countries the questions remains of filling the right job with right person at right time to do the right things. The apprehension remains in attracting the talent even; once the economic recovery takes hold. As an answer and a matter of solution, the present topic of employer branding definitely bailout the crisis in one of the many ways in resolving the staffing issues of present day organizations. According to Kotler (1994) "The task of successfully hiring, training and motivating able employees to serve the customer well is defined as internal marketing".

Therefore, an employer brand identifies and amplifies unique features that set the organization apart from the competitors. Employer brand is the extension and/or expression of organization's values and culture.

\section{Banking Sector in Saudi Arabia}

The Kingdom of Saudi Arabia even today is looked upon as a mere crude oil supplier by the outside world. Two decades ago, Saudi Arabia appeared an unlikely location for a major industrialization drives (Ramady, 2010). Saudi Arabia, a developing economy, has made steady progress with socio-economic development, gender equity, standard of living, health, education, and environmental legislation (Husain \& Khalil 2013). Saudi Arabia made significant changes in its development in all the fields including business. The country now made a mark as one of the emerging and fast developing nations in the world (Nisar Ahamad Nalband et al, 2016).

The Saudi banking sector is characterized by effectiveness, efficiency and global market (Haque \& Sharma, 2011). It is known that there are several factors behind these qualities, such as the availability of financial and technological resources, but, most important of these, is the availability of human resources who are able to manage and invest these resources efficiently and effectively.

The process of recruiting staff in Saudi organizations may collide with the prevailing culture in Saudi Arabia, where nepotism ("wasta" (a kind of recommendation)) plays an important 
role in the recruitment of many jobseekers (Fawzi and Almarshed, 2013); these aspects creates a negative employer brand image.

However, Saudi banks have realized that implications of 'wasta' will have spillover effect with which there will be damage for the brand image. Therefore, banks have found that the best methods of recruitment (Fawzi and Almarshed, 2013); to overcome the negative brand image.

The Gulf Cooperation Council (GCC) countries encouraging their nationals to accept both public and private sector jobs. The governments of these countries not only display a preference towards the employment of nationals, but also provide legislative and other support for firms employing nationals (Alserhan, 2012). So in Saudi Arabia there is a great demand for recruitment of nationals, as the research topic and the literature suggests that the organizations need to build the employer brand to attract and retain nationals and foreigners.

Attracting potential candidates is a significant issue in the recruitment process, since it involves how companies compete for often scarce skills in the labor market (Collins \& Kanar, 2013; Fernandez-Araoz, Groysberg \& Nohria, 2009; Hewlett \&Rashid, 2010). Thus, one of the contributions of this paper is to investigate the employer branding practices in Saudi Arabia banking Sector.

\section{Literature Review}

There is one component which is yet to gain momentum in today's organizations is internal marketing i.e., employer branding specifically one can call it as employer attractiveness (Berthon, Ewing, \& Hah, 2005).

Employer branding is going to be a significant approach and definitely a new practice in human resource management, it's been applied also (Martin et al. 2005, Backhaus \& Tikoo, 2004) which had drawn much attention from the academic researchers and a few consulting firms. There is a considerable literature available on theoretical foundation and conceptual frame work (Ambler \& Barrow 1996; Backhaus \& Tikoo, 2004; Edwards, 2010; Lievenset al.,2007;Moroko\& Uncles, 2009; Mosley, 2007;Wildenet al.,2010; Martin et al.,2005;Bendaravičienè, 2016), generalization and of dimensionality of employer branding (Hillebrandt \& Ivens 2013, Berthonet al.,2005), employer branding as a tool to attract potential employees (Highhouseet al.,2007:Highhouseet al., 2003;Devendorf\&Highhouse, 2008;Schreurset al., 2009; Zaveri \& Mulye 2010, Nadler et al.,2010;Ehrhart\&Ziegert, 2005, Lievenset al.,2001;Lievens, 2007;Lievens\&Highhouse, 2003; Yu, 2014, Kausel \& Slaughter, 2011;Lievenset al.,2005; Turban, 2001; Jiang \& Iles 2011; Shahzadet al.,2011), employer branding outcomes (Davies, 2008, Cable \& Edwards, 2004, Fulmer et al.,2003; Mosley, 2007), effects of corporate social performance (Turban \& Greening 1997;Albinger\& Freeman, 2000), and characteristics of successful employer brands (Moroko \& Uncles, 2008).

\subsection{Strategy and Employer Branding}

Saudi Arabia is one of the fast developing young nations which are making efforts to shift its economy from petroleum to non-petroleum. Saudi Arabia in its unique style developing its 
strengths by using high technology to meet its workforce demands for skilled and talented employees. Today's hiring manager's has tuff job of not only in retaining the existing employees but also in attracting new employees too.

Dagmar et al., 2010 in a research stated that the very important factor in achieving employer-branding objectives is to have a clearly defined employer brand strategy.

Sullivan (2004) has defined employer branding as "a targeted, long-term strategy to manage the awareness and perceptions of employees, potential employees, and related stakeholders with regards to a particular firm" (Backhaus \& Tikoo, 2004).According to Backhaus and Tikoo (2004):the term employer branding suggests the differentiation of a firms' characteristics as an employer from those of its competitors. The employment brand highlights the unique aspectsof the firm's employment offerings or environment (Chhabra \& Sharma, 2014).

In the view of Minchington (2007), in today's business environment, employer branding provides a competitive edge to acquire, nurture and retain talent. Promotion of brand within the organization will lead to an increase in employee loyalty, while the promotion of brand outside the organization will make it attractive to the potential employees

In this context, organizations may attain differentiation and become more competitive in attracting talent through Employer Branding practices/initiatives. By effectively communicating an employer's unique and positive aspects and the corresponding employment value proposition, employer branding strategies contribute to increase employer attractiveness in the labor market as a whole and, more specifically, among potential skilled candidates (Backaus \& Tikoo, 2004; Collins \& Kanar, 2013; Edwards \&Edwards, 2013; Pingle \& Sharma, 2013).

Despite of increasing visibility and relevance of employer branding for companies, there are few academic studies on the employer branding subject (Sokro, 2012). Further, literature has been mainly focused on concepts and results obtained through employer branding (Biswas \& Suar, 2014). The research on employer branding practices from HR perspective in Saudi Arabian context is almost none.

Thus, one of the contributions of this paper is to investigate the employer branding practices from the HR perspective in Saudi Arabia banking Sector.

\section{Research Methodology}

The authors like Joo and McLean (2006) have reconfirmed the opinions of many practitioners and academicians that "implementing HR best practices that support and reinforce a Best Employer culture is a good investment. Best Employer organizations tend to be stable, difficult to imitate, and provide a special and sustainable advantage over their competitors".

There seems to be many positive outcomes for an organization that brand itself with best employer practices. The present research developed a questionnaire with two parts a demographic/organizational section and attitudes of respondents towards employer branding from the HRM perspective. The second part of the questioner again divided into 6 subparts to 
enquire into 1 . Whether the organization has an employer, branding strategy is there a planning process for the same and the Dept. of HR is actively involved in or not. 2. Whether there is awareness of employer branding and practices are available or not. 3. Whether employer branding helping in attracting new employees to the organization or not. 4 . Whether top management is giving importance to employer branding strategy formulation or not. 5 . Whether there is proper co-operation and communication of employer brand exists or not. 6 . Whether there are employer branding benefits available for the organization in their recruitment process or not. The questions in the survey are designed in a simple and understandable way. Likert's five-point scale is used to measure each statement rated by the respondent's.

\section{Data Collection and Sample Size}

The research designed to be based upon data collected from the manager's level who are working in branches and head offices of the respective banks operating in Saudi Arabia. In fact there are 13 national licensed banks are operating in Saudi Arabia besides foreign licensed banks, but the data collected only from national licensed banks. From each bank 10 managers were chosen on convenient random sampling basis; a type in non-probability sampling (Saunders et al, 2009). Total number of filled in questionnaire received were 130. After checking, the filled in questionnaire found 13 questionnaires were incomplete; despite of request to the respondent's the respondent's not shown interest. Hence; the total number of filled in questionnaires are 117; the sample size is 117 for all research analysis purposes. The percentage of responses is $90 \%$.

\section{Ethical Considerations in Research}

Since the confidentiality assured to the respondents the respondents kept as anonymous. The analysis of the research results were more generalized by encompassing all the respondents' responses, no personal information in specific used/sought and simple research related questions were asked professionally. The research did not misuse nor arrive to any out of the context conclusions. Anyhow, the present research is used for academic purposes not for any commercial purpose; only for encouraging the business organizations to focus on employer branding concept.

\section{Results and Analysis}

To test the reliability of the survey instrument, the authors computed Cronbach's alpha coefficients. The overall reliability for this instrument is 0.846 , a high reliability factor. Table 1 shows the results of Reliability statistics.

Table 1. Reliability of the Instrument

\begin{tabular}{|c|c|}
\hline Cronbach's Alpha & N of Items \\
\hline .846 & 33 \\
\hline
\end{tabular}


Table 2. Mean and Standard Deviation of Factors of the study

\begin{tabular}{|l|r|r|r|}
\hline & \multicolumn{1}{|c|}{ Mean } & Std. Deviation & \multicolumn{1}{|c|}{ N } \\
\hline Planning for EB & 3.3960 & .59962 & 117 \\
Education and awareness programs of EB & 3.0513 & .72333 & 117 \\
Attracting New Employees & 3.4310 & .83447 & 117 \\
Strategy and Investment in EB & 2.6560 & .65466 & 117 \\
Cooperation of Top Management for EB & 2.8419 & .54748 & 117 \\
Benefits of EB & 3.3162 & .43184 & 117 \\
\hline
\end{tabular}

The table 2 clearly depicts that as such in Saudi Arabian banking sector the employer branding practices are not yet gained thrust; the reason can be that Saudi Arabia being the young country in business and mostly dependent on the expat workers (to whom high packages were offered) has no problems so far. Due to the changing conditions and strict imposition of Law on "Nitaqat (encouraging local's employment program)", the Saudi organizations need to recruit locals. In the present scenario of Saudi, many jobs are available for Saudis in all the Saudi Arabian business sectors including the banking sector. Therefore, it is the time for the Saudi Arabian banking sector to become cautious of employer branding practices and implement them into practice for their growth and sustainability.

Table 3. Descriptive Statistics

\begin{tabular}{|l|c|c|c|}
\hline & Mean & $\begin{array}{c}\text { Std. } \\
\text { Deviation }\end{array}$ & $\mathrm{N}$ \\
\hline Planning for EB & 3.3960 & .59962 & 117 \\
Education and awareness programs of EB & 3.0513 & .72333 & 117 \\
Attracting New Employees & 3.4310 & .83447 & 117 \\
Strategy and Investment in EB & 2.6560 & .65466 & 117 \\
Cooperation of Top Management for EB & 2.8419 & .54748 & 117 \\
Benefits of EB & 3.3162 & .43184 & 117 \\
\hline
\end{tabular}


Table 4. Item wise Mean and Standard Deviation of the Survey Instrument

\begin{tabular}{|c|c|c|}
\hline Items & Mean & $\begin{array}{c}\text { Std. } \\
\text { Deviation }\end{array}$ \\
\hline $\begin{array}{l}\text { 1.There is a centralized, specialized unit to take in charge of Employer } \\
\text { Branding planning }\end{array}$ & 3.57 & .758 \\
\hline 2.The vision and mission support the Employer Branding & 3.56 & .736 \\
\hline $\begin{array}{l}\text { 3.HR Department is involved in strategic integration of Employer } \\
\text { Branding into company's strategy }\end{array}$ & 3.41 & .779 \\
\hline $\begin{array}{l}\text { 4. HR Department represents on the steering committee of Employer } \\
\text { Branding planning. }\end{array}$ & 3.22 & .862 \\
\hline $\begin{array}{l}\text { 5. The leader's action and behaviors consistent with the Employer } \\
\text { Brand goals and values. }\end{array}$ & 3.41 & .892 \\
\hline $\begin{array}{l}\text { 6. We do adopt bench marking of successful employer branding } \\
\text { organizations. }\end{array}$ & 3.20 & .734 \\
\hline 7. We have Employer Branding educational program. & 2.83 & 1.077 \\
\hline $\begin{array}{l}\text { 8. There is an effective communication channel to communicate } \\
\text { Employer Branding information. }\end{array}$ & 2.77 & 1.012 \\
\hline 9. Employer Branding awareness programs are organized. & 3.32 & .717 \\
\hline 10. All employees participate actively in Employer Branding programs. & 3.28 & .614 \\
\hline $\begin{array}{l}\text { 11. The advertisement for recruitment are helping in attracting the new } \\
\text { employees. }\end{array}$ & 3.70 & .967 \\
\hline 12. The social media is helping in attracting the new employees. & 3.71 & .947 \\
\hline $\begin{array}{l}\text { 13. The human resource management practices and policies are helping } \\
\text { in new employees. }\end{array}$ & 3.13 & .933 \\
\hline $\begin{array}{l}\text { 14. The leadership of the organization helping in attracting new } \\
\text { employees. }\end{array}$ & 3.71 & .947 \\
\hline $\begin{array}{l}\text { 15. The career development prospectus are helping in attracting new } \\
\text { employees. }\end{array}$ & 3.15 & .877 \\
\hline $\begin{array}{l}\text { 16. The compensation, benefit, and recognition practices are helping in } \\
\text { attracting new employees. }\end{array}$ & 3.70 & 1.116 \\
\hline $\begin{array}{l}\text { 17. The transparent unbiased performance management practices are } \\
\text { helping in attracting new employees. }\end{array}$ & 2.91 & .867 \\
\hline 18. We have a clear Employer brand strategy supported with funds. & 2.21 & 1.436 \\
\hline 19. We have an unclear Employer brand strategy with funds available. & 3.23 & .932 \\
\hline 20. We have a clear Employer Brand strategy supported with funds. & 1.98 & 1.252 \\
\hline $\begin{array}{l}\text { 21. We have an unclear Employer Brand strategy not supported with } \\
\text { funds. }\end{array}$ & 3.21 & .664 \\
\hline
\end{tabular}


22.The top management is willing to give adequate time for Employer Branding Planning programs etc.

23.The leadership is supporting Employer Branding Planning, Programs etc.

24. We have sufficient funds to create a good Employer Branding.

25.No department is clear as to who is responsible for Employer Branding

26. We are into new and innovative employer Brand programs.

27. We have problems in communicating Employer Brand to potential employees, recruiters, customers and supplies.

28. Because of Employer Branding practices there is an increase in receipt of resumes from prospective employees.

29. Because of Employer Branding practices there is decrease in employee turnover rate.

30. Because of Employer Branding practices there is decrease in recruitment time.

31. Because of Employer Branding practices there is increase in job acceptance.

32. Because of Employer Branding practices there is decrease in recruitment cost.

33. Because of Employer Branding practices the company has become the employer of the choice.

From the results of the table3, the majority of the respondents felt that, at the planning level, the support required for employer branding practices is missing and HR department is not involved in employer branding at the planning level in their organizations.

The aggregate responses of the respondents is almost neutral on "education and awareness of employer branding programs is their organizations".

The respondents of the survey felt bit positively that the recruitment advertisements and social media helps in attracting new employees; further felt that the leadership of the organization, the compensation system and unbiased management practices also helping in attracting the new employees.

The respondents of the survey opined negatively about existing of employer branding strategy and availability of funds for the execution of the employer branding strategy. There might be a chance of having unstated strategy of employer branding in their organizations.

The respondents opined almost neutrally to the set of questions that deal with support and cooperation required for employer branding practices from the top management.

The respondent's opinions regarding perceived different kind of benefits respective 
respondent organizations will get because of practicingemployer-branding practices areslightly positive except the fact "there is a decrease in recruitment cost". The positive practices outcomes are because of employer branding practices there is a decrease in recruitment time (3.79), the organization became employer of the choice (3.76), there is increase in job acceptance rate (3.60), there is an increase in receipt of resumes (3.32), and there is a decrease in employee turnover rate (3.29)

Table 5. Correlation between the Factors of Analysis

\begin{tabular}{|c|c|c|c|c|c|c|c|}
\hline & & Plan & Edu & Attc & Stra & Coop & Ben \\
\hline \multirow[t]{3}{*}{ Plan } & $\begin{array}{l}\text { Pearson } \\
\text { Correlation }\end{array}$ & 1 & $.830^{* *}$ & $.388^{* *}$ & $.665^{* *}$ & $-.212^{*}$ & $.375^{* *}$ \\
\hline & Sig. (2-tailed) & & .000 & .000 & .000 & .021 & .000 \\
\hline & $\mathrm{N}$ & 117 & 117 & 117 & 117 & 117 & 117 \\
\hline \multirow[t]{3}{*}{ Edu } & $\begin{array}{l}\text { Pearson } \\
\text { Correlation }\end{array}$ & $.830^{* *}$ & 1 & $.200^{*}$ & $.779^{* *}$ & $-.209^{*}$ & $.381^{* *}$ \\
\hline & Sig. (2-tailed) & .000 & & .031 & .000 & .024 & .000 \\
\hline & $\mathrm{N}$ & 117 & 117 & 117 & 117 & 117 & 117 \\
\hline \multirow[t]{3}{*}{ Attc } & $\begin{array}{l}\text { Pearson } \\
\text { Correlation }\end{array}$ & $.388^{* *}$ & $.200^{*}$ & 1 & .065 & -.155 & .041 \\
\hline & Sig. (2-tailed) & .000 & .031 & & .485 & .095 & .664 \\
\hline & $\mathrm{N}$ & 117 & 117 & 117 & 117 & 117 & 117 \\
\hline \multirow[t]{3}{*}{ stra } & $\begin{array}{l}\text { Pearson } \\
\text { Correlation }\end{array}$ & $.665^{* *}$ & $.779^{* *}$ & .065 & 1 & .094 & $.325^{* *}$ \\
\hline & Sig. (2-tailed) & .000 & .000 & .485 & & .311 & .000 \\
\hline & $\mathrm{N}$ & 117 & 117 & 117 & 117 & 117 & 117 \\
\hline \multirow[t]{3}{*}{ Coop } & $\begin{array}{l}\text { Pearson } \\
\text { Correlation }\end{array}$ & $-.212^{*}$ & $-.209^{*}$ & -.155 & .094 & 1 & -.070 \\
\hline & Sig. (2-tailed) & .021 & .024 & .095 & .311 & & .451 \\
\hline & $\mathrm{N}$ & 117 & 117 & 117 & 117 & 117 & 117 \\
\hline \multirow[t]{3}{*}{ Ben } & $\begin{array}{l}\text { Pearson } \\
\text { Correlation }\end{array}$ & $.375^{* *}$ & $.381^{* *}$ & .041 & $.325^{* *}$ & -.070 & 1 \\
\hline & Sig. (2-tailed) & .000 & .000 & .664 & .000 & .451 & \\
\hline & $\mathrm{N}$ & 117 & 117 & 117 & 117 & 117 & 117 \\
\hline
\end{tabular}

**. Correlation is significant at the 0.01 level (2-tailed).

*. Correlation is significant at the 0.05 level (2-tailed). 


\section{Discussion}

The respondent's opinions after analysis of the data, that there is no strategy for employer branding in respondents organization, by looking at the average value, which is slightly tending towards positive side; it may be assumed that there may be unstated strategy of employer branding present.

Dagmar et al., 2010 in a research stated, "That the very important factor in achieving employer-branding objectives is to have a clearly defined employer brand strategy".

Regarding employer branding "educational and awareness programs" in the respondents organizations. Most of the respondents are silent on this aspects the calculated mean value is 3.05; in case of having good number of "educational and awareness programs" in their organizations respondents should have replied positively, because $77 \%$ of the respondents are having 2 to 4 years of experience (Table 1.6) with the current organization.

The Human Resource Practices like offering good compensation package, the performance management practices, job advertisements, usage of social media and the leadership are helping the respondent's organization in attracting the new employees. Therefore, the respondents by making use of these positive aspects by creating the good educational and awareness programs with good strategy can build their reputation very quickly.Martin R. Edwards, (2009) rightly stated that "employer branding, therefore, will involve identifying the unique "employment experience" by considering the totality of tangible and intangible reward features that a particular organization offers to its employees".

It seems there are no separate funds allotted for creating a specific employer branding strategy in the respective respondent's organization.

Over all, the support and the co-operation required for employer branding practices are missing in the respondent's organization as most of the respondents are either neutral in this regard or accepted that these aspects are missing.

Any organization when it uses any of the good practices it receives benefits. The respondents of the survey too perceived that if the employer branding practices are implemented there might be positive benefits to the organization as "The retention of employees is also one of the most important benefits that employer branding may bring. Naturally, if a company has a strong employer brand and it is seen as attractive and desirable employer, it makes it less appealing to look for another place to work at from an existing employee point of view".

\section{Conclusions}

Saudi Arabian banking sector needs to consider the aspect of employer branding seriously. Due to Saudization in the course of time, becomes very tuff for them to attract and retain the talented human resources.

Dell and Ainspan (2001) strongly argues, "The employer brand establishes the identity of the firm as an employer. It encompasses the firm's values, systems, policies, and behaviors toward the objectives of attracting, motivating, and retaining the firm's current and potential 
employees". The Saudi banking sector employers needs to align the policies, procedures, behaviors and strategies towards establishing a good employer brand.

The employer brand can be created and reinforced through proper communication, by creating awareness among the employees as to what is employer branding. In Saudi Arabian banking, sector this aspect need to be improved

In Saudi Arabian present context as well as "according to Mandhanya and Maitri (2010), today there is less talent and the talent has more and more choices regarding the career options. Now companies have a problem as to how to attract these talents and retain them".

One of the main purpose of employer branding is to attract as many as number of applicants with right competencies. For an organization with good employer brand, it would not have to search the talent; the talent itself will be searching for the organization."This means that branding would be used in a way that helps the company to achieve the employer of choice status in the labor market (Taylor, 2010, p.198)". The Saudi Arabian banking sector has to realize the fact that with good employer branding practices "the recruitment process cost and time can be saved".

In today's business scenario of war for talent, "before a company can make their customers satisfied they need to succeed in making their employees satisfied (Mandhanya \& Maitri, 2010). This is possible only with having positive employer brand.

Saudi Arabian business sector in general and banking sector in specific are growing day by day, the application of "Nitaquat (reservation of jobs for locals)" in the country. This fact keeping all the hiring departments in Saudi Arabian business sector on a high alert. Right now, too many jobs are available for a few talented locals.

In the coming days there will be an increase in the supply of local talent in Saudi Arabia as many young locals are going joining the labor market finishing their education.

Therefore, there is a dire need on the part of the Saudi Arabian organizations to create and practice "employer branding". However, "despite the great popularity of employer branding among practitioners, research in the field still poses a number of critical questions and issues for management scholars, such as the lack of knowledge on how organizations should develop and implement effective employer branding (Backhaus \&Tikoo 2004, Edwards 2010)", "unclear link between employer branding and organizational outcomes (Backhaus \& Tikoo 2004)".

\section{Future Scope for Research:}

The present research focusing on banking sector only, there is a good scope for a comparative study of employer brand practices in different sectors of the business.

A model on "employer branding" needs to be established as to what the best employer branding practices are and how these practices help the organizations in attracting and retaining the best talent with minimum effort and cost. 


\section{Acknowledgement}

The authors extend their appreciation to the Deanship of Scientific Research at King Saud University represented by the Research Centre in the College of Business Administration for financially supporting this research.

\section{References}

Aaker, D. (1991). Managing brand equity. New York: Free Press.

Albinger, H. S., \& Freeman, S. J. (2000).Corporate Social Performance and Attractiveness as an Employer to Different Job Seeking Populations. Journal of Business Ethics, 28(3), 243-253. https://doi.org/10.1023/A:1006289817941

Alserhan, B. A. (2012). Branding Employment Related Public Policies: Evidence from a Non-Western context. Employee Relations, 35(4), 423-440. https://doi.org/10.1108/ER-09-2012-0065

Ambler, T., \& Barrow, S. (1996). The employer brand. The Journal of Brand Management, 4, 185-206. https://doi.org/10.1057/bm.1996.42

Ambler, T. (1997). How Much of Brand Equity Is Explained By Trust? Management Decision, 35(4), 283-292. https://doi.org/10.1108/00251749710169666

Backhaus, K., \& Tikoo, S. (2004). Conceptualizing and Researching Employer Branding. Career Development International, 9(5), 501-517. https://doi.org/10.1108/13620430410550754

Bendaravičienè, R. (2016). Theoretical Perspectives for Employer Branding. Journal of Advanced Research in Management, 1(13), 5-27.

Berthon, P., Ewing, M., \& Hah, L.L. (2005).Captivating Company Dimensions of Attractiveness in Employer Branding. International Journal of Advertising, 24(2), 151-172. https://doi.org/10.1080/02650487.2005.11072912

Biswas, M., \& Suar, D. (2014).Antecedents and Consequences of Employer Branding. Journal of Business Ethics. https://doi.org/10.1007/s10551-014-2502-3

Cable, D. M., \& Edwards, J. R. (2004). Complementary And Supplementary Fit: A theoretical and empirical integration. Journal of Applied Psychology, 89(5), 822-834. https://doi.org/10.1037/0021-9010.89.5.822

Campbell, M. C. (2002). Building Brand Equity. International Journal of Medical Marketing, 2(3), 208-218. https://doi.org/10.1057/palgrave.jmm.5040078

Caplan, J. (2004). Building a winning employer brand, China Staff, Hong Kong, Dec 2003/Jan 2004, 10(2) 1-5. Retrieved March 8, 2011, from http://findarticles.com/p/articles/mi_qa5478/is_2003

Chhabra, N.L., \& Sharma, S. (2014). Employer branding: strategy for improving employer attractiveness. International Journal of Organizational Analysis, 22(1), 48-60. 
https://doi.org/10.1108/IJOA-09-2011-0513

Collective Learning Australia. (2010). 319 p. ISBN 978-0-646-53648-4

Collins, C., \& Kanar, A. (2013).Employer brand equity and recruitment research. In: Yu, K; Cable, D. (eds.) The Oxford Handbook of Recruitment. Oxford Library of Psychology.

Dagmar babčanová ,miroslavbabčan, \& evaodlerová. (2010). employer branding - source of competitiveness of the industrial plants; research papers faculty of materials science and technology in trnavaslovak university of technology in bratislava, 2010 number 29.

Davies, G. (2008). Employer Branding and Its Influence on Managers. European Journal of Marketing, 42(5/6), 667-681. https://doi.org/10.1108/03090560810862570

Dell, D., \& Ainspan, N. (2001). Engaging Employees Through Your Brand. Conference Board Report No. R-1288-01 RR, Conference Board, Washington, D.C. Ewing, M.T., Pitt, L.F., de Bussy, N.M., \& Berthon, P. (2002), "Employment branding in the knowledge economy". International Journal of Advertising, 21(1), 3-22. https://doi.org/10.1080/02650487.2002.11104914

Devendorf, S. A., \& Highhouse, S. (2008). Applicant-Employee Similarity and Attraction to an Employer. Journal of Occupational and Organizational Psychology, 81(4), 607-617. https://doi.org/10.1348/096317907X248842

Edwards, M. R. (2010). An Integrative Review of Employer Branding and OB Theory. Personnel Review, 39(1), 5-23. https://doi.org/10.1108/00483481011012809

Edwards, M., \& Edwards, T. (2013). Employee Responses to Changing Aspects of the Employer Brand Following a Multinational Acquisition: A longitudinal study. Human Resource Management, 52(1), 27-54. https://doi.org/10.1002/hrm.21519

Ehrhart, K. H., \& Ziegert, J. C. (2005). Why Are Individuals Attracted To Organizations? Journal of Management, 31(6), 901-919. https://doi.org/10.1177/0149206305279759

Fernandez-Araoz, C., Groysberg, B., \& Noharia, N. (2009).The Definite Guide to Recruiting In Good Times and Bad. Harvard Business Review, 87(5), 74-84.

Fill, C. (2006). Simply Marketing Communications. Essex: Pearson Education Limited.

Fulmer, I. S., Gerhart, B., \& Scott, K. S. (2003). Are the 100 best better? An empirical investigation of the relationship between being a "great place to work" and firm performance. Personnel Psychology, 56(4), 965-993. https://doi.org/10.1111/j.1744-6570.2003.tb00246.x

Hewlett, A., \& Rashid, R. (2010).The Battle for Female Talent in Emerging Market. Harvard Business Review, 88(5), 101-106.

Highhouse, S., Lievens, F., \& Sinar, E. F. (2003).M easuring Attraction to Organizations. Educational and Psychological Measurement, 63(6), 986-1001. https://doi.org/10.1177/0013164403258403 
Highhouse, S., Thornbury, E. E., \& Little, I. S. (2007). Social-Identity Functions of Attraction to Organizations. Organizational Behavior and Human Decision Processes, 103(1), 134-146. https://doi.org/10.1016/j.obhdp.2006.01.001

Hillebrandt, I., \& Ivens, B. S. (2013). Scale Development in Employer Branding. Impulse für die Markenpraxis und Markenforschung, Tagungsband der internationalenKonferenz, Der Markentag 2011“, Springer Fachmedien Wiesbaden, 65-86. https://doi.org/10.1007/978-3-658-00427-9_4

Husain T, Khalil AA. (2013). Environment and Sustainable Development in the Kingdom Of Saudi Arabia: Current Status and Future Strategy. J Sustainable Dev., 6, 14-30. https://doi.org/10.5539/jsd.v6n12p14

Jiang, T., \& Iles, P. (2011).Employer-Brand Equity, Organizational Attractiveness and Talent Management in the Zhejiang Private Sector, China. Journal of Technology Management in China, 6(1), 97-110. https://doi.org/10.1108/17468771111105686

Kausel, E. E., \& Slaughter, J. E. (2011). Narrow Personality Traits and Organizational Attraction: Evidence for the Complementary Hypothesis. Organizational Behavior and Human Decision Processes, 114, 3-14. https://doi.org/10.1016/j.obhdp.2010.08.002

Kotler, P. (1994). Marketing Management: Analysis, Planning, Implementation and Control, ( ${ }^{\text {th }}$ ed.), Prentice-Hall, Englewood Cliffs, NJ.

Kroustalis, C.M., \& Meade, A. W. (2007). Portraying an Organization's Culture through Properties of a Recruitment Website. Paper presented at the 22nd Annual Meeting of the Society for Industrial and Organizational Psychology, New York, Retrieved from http://www4.ncsu.edu/ awmeade/Links/Papers/Internet_Recruit(SIOP07).pdf

Lievens, F. (2007). Employer branding in the Belgian army: The importance of instrumental and symbolic beliefs for potential applicants, actual applicants, and military employees. Human Resource Management, 46(1), 51-69. https://doi.org/10.1002/hrm.20145

Lievens, F., \& Highhouse, S. (2003). The Relation Of Instrumental and Symbolic Attributes to a Company's Attractiveness As An Employer. Personnel Psychology, 56(1), 75-102. https://doi.org/10.1111/j.1744-6570.2003.tb00144.x

Lievens, F., Decaesteker, C., Coetsier, P., \& Geirnaert, J. (2001). Organizational Attractiveness for Prospective Applicants: A person-organization fit perspective. Applied Psychology: An International Review, 50, 576-587. https://doi.org/10.1111/1464-0597.00047

Lievens, F., Hoye, G. V., \& Schreurs, B. (2005). Examining the relationship between employer knowledge dimensions and organizational attractiveness: An application in a military context. Journal of Occupational Psychology, 78, 553-572. https://doi.org/10.1348/09631790X26688

Mandhanya, Y., \& Maitri, S. (2010). Employer branding: A tool for talent management. Global Management Review, 4(2), 43-48. 
Martin R. Edwards, (2009). An Integrative Review of Employer Branding And OB Theory. Personnel Review, 39(1), 5-23. https://doi.org/10.1108/00483481011012809

Martin, G., Beaumont, P., Doig, R., \& Pate, J. (2005). Branding: a new performance discourse for HR? European Management Journal, 23(1), 76-88. https://doi.org/10.1016/j.emj.2004.12.011

Martin, G., Beaumont, P., Doig, R., \& Pate, J. (2005). Branding: A new performance discourse for HR? European Management Journal, 23(1), 76-88. https://doi.org/10.1016/j.emj.2004.12.011

Meffert, H., Burmann, C., \& Koers, M. (2002). Markenmanagement-Grundfragenderidentit"atsorientiertenMarkenf"uhrung. Wiesbaden, Germany: Gabler. https://doi.org/10.1007/978-3-322-92976-1

MINCHINGTON, B. Employer Brand Leadership - A Global Perspective. Torrensville: Nadler, J.T., Cundiff, N.L., Lowery, M.R., \& Jackson, S. (2010). Perceptions of Organizational Attractiveness: The differential relationships of various work schedule flexibility programs. Management Research Review, 33(9), 865-876. https://doi.org/10.1108/01409171011070297

Moroko, L., Uncles, M.D. (2008). Characteristics of Successful Employer Brands. Journal of Brand Management, 16(3), 160-175. https://doi.org/10.1108/01409171011070297

Moroko, L., \& Uncles, M.D. (2009). Employer Branding and Market Segmentation.Journal of Brand Management, 17(3), 181-196. https://doi.org/10.1057/bm.2009.10

Mosley, R. (2007). Customer Experience, Organizational Culture and the Employer Brand. Brand Management, 15(2), 123-134. https://doi.org/10.1057/palgrave.bm.2550124

Nadler, J.T., Cundiff, N.L., Lowery, M.R., \& Jackson, S. (2010). Perceptions of Organizational Attractiveness: The differential relationships of various work schedule flexibility programs. Management Research Review, 33(9), 865-876. https://doi.org/10.1108/01409171011070297

Nalband, N.A., Alkeleabi, S., \& Jabber, D. A. (2016). Innovation Practices in Saudi Arabian Businessses, International Journal of Business and Management; 11(4), 136-160. https://doi.org/10.5539/ijbm.v11n4p136

Petkovic, M. (2004). GeschickteMarkenpolitik. Personal, 4(6).

Pingle, S., \& Sharma, A. (2013). External Employer Attractiveness: A Study of Management Students in India. Journal of Contemporary Management Research, 7(1), 78-95.

Ramady, M. A. (2010). The Saudi Arabian Economy: Policies, Achievements, and Challenges ( $2^{\text {nd }}$ ed.). Springer, NY. https://doi.org/10.1007/978-1-4419-5987-4

Rucci, A.T., Kirn, S.P., \& Quinn, R.T. (1998).The Employee-Customer-Profit Chain at Sears.Harvard Business Review, 76, 82-97. 
Sartain, L. (2005). Branding from the inside out at Yahoo!: HR's role as brand builder.Human Resource Management, 44(1), 89-93. https://doi.org/10.1002/hrm.20045

Schreurs, B., Druart, C., Proost, K., \& Witte, K. D. (2009).Symbolic Attributes and Organizational Attractiveness: The moderating effects of applicant personality. International Journal of Selection and Assessment, 17(1), 35-46. https://doi.org/10.1111/j.1468-2389.2009.00449.x

Shahzad, K., Gul, A., Khan, K., \& Zafar, R. (2011).Relationship between Perceived Employer Branding and Intention to Apply: Evidence from Pakistan. European Journal of Social Sciences, 18(3), 462-467.

Sivertzen, A., Nilsen, E. R., \& Olafsen, A. H. (2013). Employer Branding: Employer Attractiveness and the Use of Social Media. Journal of Product and Brand Management, 22(7), 473-483. https://doi.org/10.1108/JPBM-09-2013-0393

Sokro, E. (2012). Impact of Employer Branding On Employee Attraction and Retention. European Journal of Business and Management, 4(18), 164-173.

Sullivan, J. (2004). Eight elements of a successful employment brand. ER Daily, 23 February,

Sutherland, M.M., Torricelli, D.G., \& Karg, R.F. (2002). Employer-of-choice branding for Knowledge workers. South African Journal of Business Management, 33(4), 13-20.

Taylor, S. (2010). Resourcing and Talent Management.(5 ${ }^{\text {th }}$ edition). London: Chartered Institute of Personnel and Development.

Turban, D. B. (2001). Organizational Attractiveness as an Employer on College Campuses: An Examination of the Applicant Population. Journal of Vocational Behavior, 58(2), 293-312. https://doi.org/10.1006/jvbe.2000.1765

Turban, D.B., \& Greening, D.W. (1997).Corporate Social Performance and Organizational Attractiveness to Prospective Employees. Academy of Management Journal, 40(3), 658-672. https://doi.org/10.2307/257057

Wilden, R., Gudergan, S., \& Lings, I. (2010). Employer Branding: Strategic implications for staff recruitment. Journal of Marketing Management, 26(1-2), 56-73. https://doi.org/10.1080/02672570903577091

Yu, K.Y.T. (2014). Person-Organization Fit Effects On Organizational Attraction: A test of an expectations-based model. Organizational Behavior and Human Decision Processes, 124, 75-94. https://doi.org/10.1016/j.obhdp.2013.12.005

Zaveri, M., \& Mulye, R. (2010). Country of origin effect and employer attractiveness: A missing link, in Paul Ballantine and DrJorgFinsterwalder (Ed.) Proceedings of the Australian and New Zealand Marketing Academy Conference 2010, Christchurch, New Zealand, 29 November - 1 December 2010. 